Journalof Sustainable Tourism

\title{
Venice as a short-term city. Between global trends and local lock-ins
}

\section{Giacomo-Maria Salerno \& Antonio Paolo Russo}

To cite this article: Giacomo-Maria Salerno \& Antonio Paolo Russo (2020): Venice as a shortterm city. Between global trends and local lock-ins, Journal of Sustainable Tourism, DOI: 10.1080/09669582.2020.1860068

To link to this article: https://doi.org/10.1080/09669582.2020.1860068

曲 Published online: 30 Dec 2020.

Submit your article to this journal

Llll Article views: 106

Q View related articles $₫$

View Crossmark data $\nearrow$ 


\title{
Venice as a short-term city. Between global trends and local lock-ins
}

\author{
Giacomo-Maria Salerno $^{\mathrm{a}}$ (D) and Antonio Paolo Russo ${ }^{\mathrm{b}}$ (D) \\ a'Department of Civil, Building and Environmental Engineering (DICEA), Sapienza Università di Roma, Italy; \\ ${ }^{\mathrm{b}}$ Department of Geography, University Rovira i Virgili, Vila-seca, Spain
}

\begin{abstract}
This paper examines the ongoing transition of Venice towards a shortterm city, posited as an urban form which accommodates the dwelling practices of temporary populations as tourists, at the expenses of a stable resident population. This shift is approached through the conceptual framework of resilience, which is also explored in its political and discursive dimensions. At the base of the emergence of a short-term city, we analyse the redistributive impacts of short-term rentals mediated by digital platforms and their influence on the housing market, but also the related entrenchments of a local policy agenda supporting the resilience of the industry itself above that of the city as a living organism. After illustrating the development of the hospitality sector in the city fabric over the last four decades and presenting the historical challenges that Venice has been facing in regard to its capacity to retain a stable population, we seek to unravel the debate on the future of Venice', which confronts local and global agents defending a 'conservationist' approach for Venice as an ineluctably tourist city, with social actors who claim for the defence of residence - and therefore for a ban on STR - as a necessary condition for a socially resilient alternative.
\end{abstract}

\section{ARTICLE HISTORY}

Received 17 February 2020

Accepted 29 November 2020

\section{KEYWORDS}

Overtourism; resilience; short-term rentals; Venice; housing; depopulation

\section{Introduction}

The rise of 'platform capitalism' (Srnicek, 2017) and its articulation in the hospitality sector as platform-mediated short-term rentals (henceforth: STR) may well be the last critical nudge for Venice towards a destiny of city without residents, or, as we propose in this paper, a short-term city. One of the most attractive destinations worldwide, and iconized in the popular global imagery well before the XX century (Davis \& Marvin, 2004), Venice has grown increasingly dependent on tourism at least since the late 1970s, when the proliferation of hotels and tourist services started to flank the progressive loss of economic functions, with regulations and policy regimes eventually adapting and favouring such changes. While the increased orientation towards the visitor economy and the progressive intensification of the use of space by visitors (Indovina, 1988) has gone hand-in-hand with processes of displacement of the resident population, marking a steady erosion of the city's social mass (Costa \& Martinotti, 2003; De Rita, 1993; Fregolent \& Vettoretto, 2017; Minoia, 2017; Russo, 2002a), the uptake of the housing market by 
STR since the early 2010 has driven the domain of tourist commodification to an unprecedented scale.

For decades, the debate on the 'future of Venice' has been prominent in society and institutions at state, regional and local level. Yet the policies implemented have mainly been in the realm of physical conservation, and in 2020 the future of Venice as a living city looks dimmer than ever. Submerged by tourism and simultaneously becoming more vulnerable and dependent by the day, the question as to whether it will also remain attractive, and at what cost for a resident population, has been risen by several scholars (e.g. Seraphin et al., 2018), but also by the public opinion locally and globally. This reflection becomes even more relevant in the wake of the abrupt downsizing of tourism activity provoked by COVID-19. Contrasting with the bleak figures on losses in the tourism sector (13,2 million visitors, 3 billion Euros of turnover and 26,000 jobs lost with respect to 2019), commentators have been surprisingly reporting the momentary relief from tourism pressure that has been enjoyed by the Venetian population during the first part of the high season of 2020 (Momigliano, 2020). This paradoxical situation has revamped the debate on the future of Venice and its tourism, and is also likely to shape the post-COVID debate, when, as in other places, advocates of full recovery and the global agencies that will push in that direction will be faced with mounting arguments in favour of reforms towards greater resilience (Gössling et al., 2021).

Venice has been noted as an early - and epitomic - case of what has recently come to be called 'overtourism' (Milano et al., 2019a), denoting not only a strong and increasing tourism pressure on destination spaces, but most significantly the magnitude of its environmental and social effects, the most remarkable of which are possibly the unaffordability of housing for residents and for the very workers of the tourism industry. Such issues have been noted in Venice for a very long time (at least since the seminal report COSES 1979), and Venice has frequently been described as 'worst case scenario' in the tourism planning literature. Yet it could be argued that the situation of Venice realigns with many other overtouristed cities where the 'touristification of housing', through the conversion of a substantial part of the city's residential stock to short-term vacational rentals, is considered a critical factor of acceleration and extension of the disruptions produced by tourism. The burgeoning literature on the impacts of STR hints at the shrinking of affordable housing supply, the rise of rents, and the associated interrelated processes of capital concentration and exclusion and displacement (Barron et al., 2017; Celata et al., 2017; Cocola-Gant \& Gago, 2019; Lee, 2016; Wachsmuth et al., 2017; Wachsmuth \& Weisler, 2018). All this is happening in Venice, only at a possibly grander scale and in the context of a six-decade struggle for its very survival in an extremely delicate ecosystem - fragile, expensive, and increasingly marginal from a political, economic and cultural perspective.

The scholarly and societal debate on Venice's overtourism has been focusing on other - certainly relevant - aspects, such as the endogenous transformation of the tourist marketplace towards low quality (Caserta \& Russo, 2002), the impacts of cruise tourism (Vianello, 2016), or the regional scale of tourism activity and the differential and interrelated impacts of overnight stayers and excursionists (Costa \& Van Der Borg, 1988; Russo, 2002b). Yet the degree at which STR have been taking over Venice's housing market calls for a fresh examination of the effects that this is having on the city - and may have in the long run - and of the opposing positions in the debate on whether this form of accommodation should be regulated, how, and of the alternative visions on the future of Venice as a city with a resident population. In this sense, the peculiarity of Venice's territorial conformation, in which the modern urban expansion of the city remains physically separated from the insular historical (and tourist) core, requires a specific understanding of how the intersection between a long-standing tourist saturation and the new frontiers of platform capitalism represented by STR could lead to the risk of collapse of the city's capacity of social reproduction, envisaging the emergence of what could be called a shortterm city. 
In this paper, we are introducing this term as an analytical dimension of urban change which may tie into the resilience debate. By short-term city we denote an urban form that is not anymore anchored to - and dependent on - a resident population: it reorients to the transits and dwelling practices of a transient population like short term-visitors, while the mass of the stable population shrinks. The case of Venice provides insights on how these two dynamics may be interrelated, looking at historical lock-ins as well at causal relations. In this sense, we posit the emergence of the short-term city as a specific effect of overtourism, based on a housing market increasingly geared on the practices and affordabilities of a population of transient dwellers. Ultimately, we seek to contribute to the wider debate on place resilience taking in the dimension of tourism mobilities and temporary uses. Are short-term cities resilient? Or are these two characteristics inherently in opposition? How can this question be framed in the scholarly debate on place resilience, sustainable tourism and overtourism, and how does the case of Venice presented here illuminate on such issues?

Place resilience, a concept derived from disaster studies and challenging the approach based on sustainability in the analysis of the transformation of socio-economic systems (Mehmood, 2016; Vale \& Campanella, 2005), seems particularly adequate in providing a conceptual framework of reference for the short-term city, even more so in pandemic times. Beyond the efforts to emancipate resilience from emergency planning towards a progressive and evolutionary perspective (Davoudi et al., 2012), shock situations as the Covid-19 outbreak may highlight to a greater extent the unsustainability inscribed in the pre-disaster conditions. Moreover, a resilience framework could be a better way to embrace the political dimension of place transformations: firstly, because resilience studies are progressively turning from the bounce-back-ability of the examined system to its capacity of 'bouncing forward' to a more sustainable state (Shaw, 2012), questioning and challenging the "profound inequality" on which the previous state was built upon (Vale, 2014); secondly, because the hegemonic struggle between different groups for the definition of resilience criteria (Paidakaki \& Moulaert, 2017a, 2017b) nuances a 'politics of resilience', in which it is key to unravel implicit answers to questions such as "who counts as 'the city'? (And who decides who counts as 'the city'?)" (Vale, 2014, p. 197), or "resilience for whom and against what?" (ibid, p. 191).

This approach paves the way to a transformative use of the resilience concept, disentangling it from a dominant neoliberal semantisation and reframing it in a right to the city perspective (Meriläinen et al., 2020), as subversive resilience (Grove, 2013). In the specific field of tourism studies, the concept of resilience has largely focused on the capacity of recovery of the tourism industry in the aftermath of catastrophic events (Lew, 2014). Our interest in place resilience refers, instead, to the capacity of the urban organism that is a tourist destination to reproduce itself socially, while evolving towards conditions of spatial and social justice. This, we claim, is at stake in the context of the tourist monoculture in which Venice seems trapped (Salerno, 2020), an overspecialisation that - as we argue in this paper - extends critically to housing as key resource for social reproduction. It has indeed been shown that resilience is threatened "within social systems that are dependent on a single ecosystem or single resource" (Adger, 2000, p. 350), and in this regard Venetian tourist monoculture is no exception (Cristiano \& Gonella, 2020). Moreover, hazardous resource dependency is not the only reason for which touristification could be seen as a threat to resilience, if the latter is not understood within a neo-liberal framework but comprehends justice as one of its key features (Davoudi et al., 2012). Economic and demographic aspects such as uneven distributional effects in terms of income or population displacement processes, could be interpreted per se as indicators of the lack or breakdown of resilience (Adger, 2000), even in the absence of catastrophic events.

The structure and methodology of this paper is inductive, seeking to build new general knowledge from existing empirical evidence. Thus, we first introduce the main coordinates of the debate on the 'future of Venice' and its evolution as an overtouristed destination. We focus on the recent evidence on the reconfiguration of the Venetian real estate market triggered by the 
rise of STR, examining their 'exceptional' character in relation to previous trends. Although we mostly use secondary sources and data, we interrogate the literature to make sense of such trends and propose an original interpretation. We then discuss the politics underlying the different stages in the construction of Venice as a short-term city, looking at the different positionings and discourses deployed along such evolution, gathered from media pieces and public statements. In the last section, we refer back to the debate on place resilience and (sustainable) destination development, proposing that the case of Venice and its evolution as a short-term city could be considered a 'template' of how overtourism can pose a serious threat to place resilience, and insisting on the existence of alternatives that should orient policy initiatives at different scales. We also engage critically with the Tourism Carrying Capacity analytical approach to set targets for sustainable tourism - but possibly ignoring resilience - and propose instead a 'subversive resilience' policy approach with a key focus on housing use regulations and economic diversification.

\section{The 'tourist destiny' of Venice: from iconisation to socio-spatial stratification}

The enmeshment and signification of Venice with its tourism is obviously not new. Already in the 19th century, several classical authors would define Venice as a "visitable past" (James, 1888, p. 31), a place that "scarcely exists any more as a city at all; [a place] that exists only as a battered peep-show and bazaar" (James, 1909, p. 12), "half fairy-tale and half tourist trap" (Mann, 1912 , p. 45). The re-production of Venice as tourist attraction has been a longstanding process rooted both in the peculiar characteristics of the city (Davis \& Marvin, 2004; Salerno, 2020) and in the modern history of urban transformations, marked by dynamics of implosion/explosion and heritagization (Choay, 1996; Lefebvre, 1970). This process may represent an early example of iconisation or Disneyfication of an historical landscape (Cosgrove, 1982), to be tracked down at least to the Romantic period (Bettini, 1978).

The acceleration of the tourist nature of the city could however be situated in the 20th century, when Venice started its modern expansion into the mainland, while the insular historical city (henceforth: $\mathrm{HC}$ ) became the object of strict conservation intended to preserve its value and maintain its main functions as an international pole of arts, culture and entertainment (Fregolent \& Vettoretto, 2017). Indeed, during the last 60 years, Venice's HC has been going through an articulate process of population restructuring by which "poor and low-middle classes [had] no other choice than to move out of the city centre, and possibly become daily commuters involved in servient economies exploiting the city landscape" (Minoia, 2017, p. 263). Since the construction of the industrial settlement of Marghera in 1917, the population of the Venetian mainland has been growing steadily, while the population of the HC shrunk to less than a third compared to the post-war period (see left axis of Figure 1, in lines). This evolution nuances a "spatially separated urban society", in which the working and middle classes flee with jobs to the mainland, while insular Venice remains mainly a site of residence for upper class rentiers (Fregolent \& Vettoretto, 2017, pp. 83-84). Since the 1960s, this relentless process of depopulation has been tagged in Venetian chronicles as 'the exodus' (Zanardi, 2020), one of the key issues of the socalled "Problem of Venice" (Comune di Venezia, 1964).

At the same time, tourist activity in the city increased constantly (see right axis of Figure 1, in columns). Zannini (2014) identifies two main phases of tourism growth in Venice in the 20th century: the former, from the post-war period to the 1980s, consists of an élite market developing into proper mass tourism (with a constant growth of arrivals from a total 1,669,000 in 1952 to the $4,389,000$ of 1992). The latter stage - from the 1990 s to present days - is characterized by the rise of global 'postmodern' tourism trends, by national and local easing on urban regulations, and by the simultaneous decline of Marghera's industrial strength. In this stage, the growth curve undergoes a further surge (Barbiani \& Zanon, 2004), reaching the most recent official 


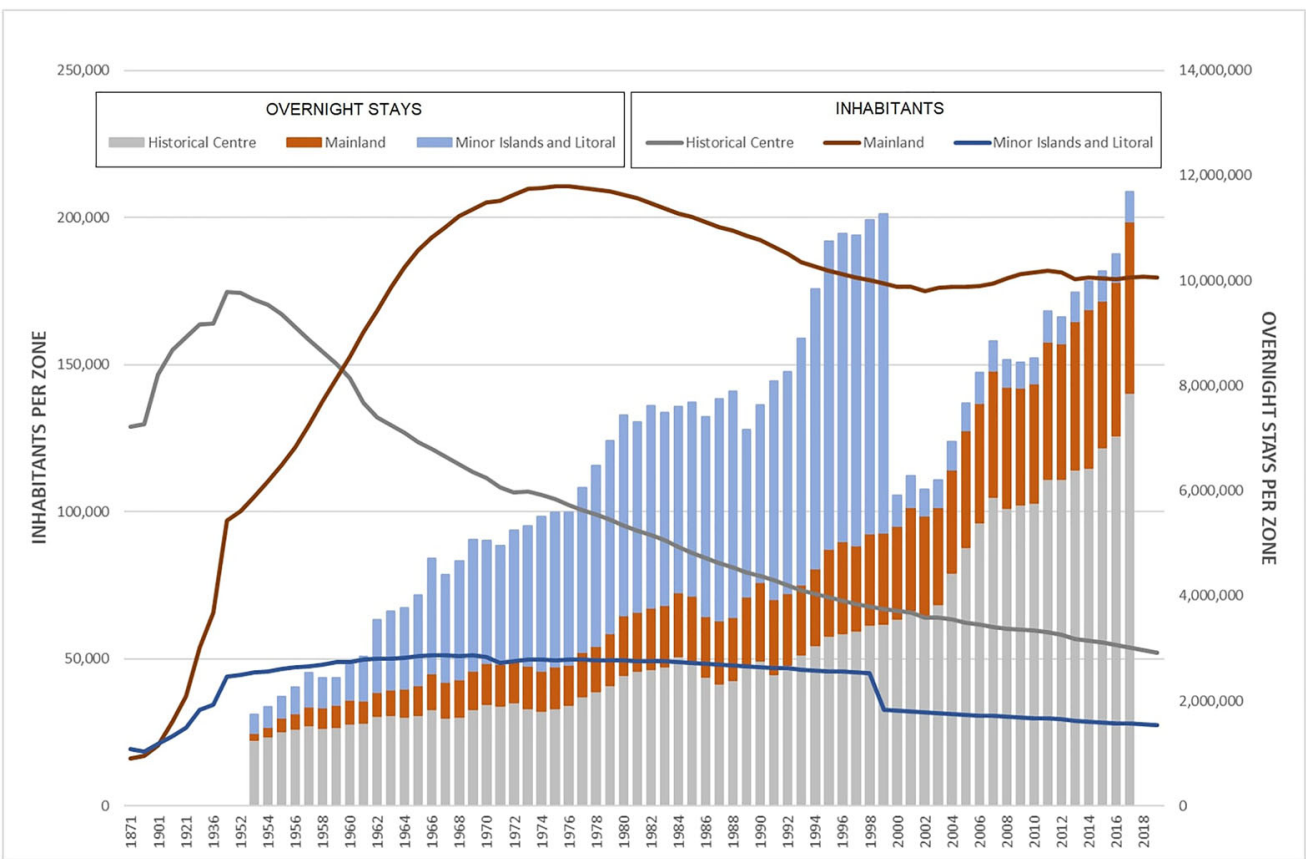

Figure 1. Evolution of inhabitants (1871-2019) and overnight stays (1953-2017) in different sections of the Municipality of Venice. ${ }^{1}$

estimation of around 28 million visitors a year (30 million for Lanapoppi, 2015), an 80\% of which are day visitors, a trend which is "decisively upwards" (Van Der Borg, 2017, p. 15). This quantity of visitors pouring into the city yields an average visitors-per-resident/day ratio of more than 1.5, or, in other words, " 500 visitors per year for each resident of the 750 hectares of the historical urban fabric" (Fabbri et al., 2020, p. 41).

Venice's everyday scenario, then, goes far beyond the Tourist Carrying Capacity (henceforth: TCC) threshold identified by Costa and Van Der Borg (1988), who fixed in 20,750 visitors per day the maximum tolerance of Venice's services, subdivided into 13,000 overnight stays and less than 8,000 day visits, for a total of around 7.5 million yearly presences in the HC. That limit that was surpassed for two thirds of the days in the year then, and it is widely surpassed almost any day of the year today, when daily presences of visitors average around 80,000. The TCC approach has conceptual and empirical limitations as a target for a resilient city, as will be discussed below. However, this situation can certainly be defined as an over- or hyper-tourism scenario, which Costa and Martinotti (2003, p. 61) identified in socio-demographic terms as one in which the use of the city by visitors exceeds that of residents, defining it as a site of predominant tourist consumption. This definition of a hyper-tourist city is echoed by that given, with a more elastic formulation, by D'Eramo, who argues that the threshold that "separates a tourist city from a city that also lives on tourism" is the one that marks the passage from a situation in which "tourists benefit from services and facilities designed for residents", and one in which "residents are forced to use services designed for tourists" (D'Eramo 2017, p. 72).

From this point of view, the situation of Venice would seem to swing dangerously on the edge of the "transition phase" (ibid.) from a proper urban organism to a wholly touristified space. Referring back to the resilience literature, continuous incremental change has brought the city to the brink of a qualitative shift (Lew, 2014) after which it is no longer perceived by a part of its residents as belonging to them, but more as "a simulacrum of an inhabitable space that no longer exists" (De Rita, 1993). This argument reflects the debate on the loss of sense of place (Davidson \& Lees, 2010) for the local community when space adapts to other uses and market 
forces. This is particularly evident in relation to commercial activities, which are radically reorienting their offer and image to the transient visitor demand (Gheno, 2016; Russo, 2002a) to the detriment of proximity commerce, a process encouraged by national liberalization laws (the so called Bersani law of 2006). The earnings required to cover the costs of renting and running a shop in the HC make it impossible to cater for the everyday necessities of the few remaining inhabitants (Scheppe et al. 2009). The whole economic fabric of the city then faces a metamorphic wave by which "every store that sell stationery, hardware, groceries and the like, is being converted into a uniform space offering fake Murano glass or imitations of Carnival masks" (ibid, p. 290). This further reduces the opportunities and affordability of everyday routines for residents, whose 'reaction tactics' range from drawing increasingly out of the most congested areas (Quinn, 2007) to abandon the city altogether, reproducing the 'exodus'.

To summarize, Venice could be considered a school case for overtourism, in which the presence of visitors "invades, suffocates and distorts the physical city and overturns the very life of its inhabitants" (Fabbri et al., 2020, p. 41). In the next section, we will then discuss how the impact of platform capitalism on Venetian housing market has strongly worsened an already deteriorated situation.

\section{From the 'hotelisation' of the city to the touristification of housing}

To reconstruct the role that the affirmation of short-term rentals as dwelling modality in in Venice may have played in the emergence of the short-term city, we will situate these trends against the broader dynamics of the hospitality sector and of the housing market.

At the turn of the XX century, Venice already hosted a substantial number of hotels and boarding houses (Bernardello, 2002; Zannini, 2002). As the data on overnight stays presented in the previous section suggest, the supply of accommodation has been growing steadily during the post-war expansion and the consolidation of Venice as a mass-tourism destination since the 1970s. This growth has gone through different stages. Until the end of the 1990s, planning regulations on land uses and hospitality prevented expanding the supply in the hotel sector beyond a limit of 11,000 bedplaces, while housing rentals for short periods, or for rooms, were strictly regulated. In 1997, an amendment to the planning regulations for the HC gave way to a substantial number of conversions from residential to tourist use; in the same period, the cap on hotel bedplaces offered in the $\mathrm{HC}$ was progressively released. In the verge of a few years, the supply increased by $30 \%$ in the HC, reaching in 2003 the number of 16,650 beds in hotels and 2,500 new bedplaces in 'other forms of accommodation' (Barbiani \& Zanon, 2004, p. 9). Yet these figures are quite small compared with the most recent ones: in the first decade of the 2000s, the number of establishments was tripled, introducing around 10,000 new bedplaces in the market; the main driver of this growth is the non-hotel sector, whose establishments multiplied by 10 in 8 years (COSES 2009a, p. 47). This extraordinary expansion reflects a new global trend in the hospitality industry, in which the non-hotel sector has been taking advantage of deregulation policies and of the extension of internet as a commercialisation channel.

Even before the appearance of STR, the housing market was already strongly bent on Venice's tourist appeal. In 2007, one of three houses was bought by a foreigner. The attractiveness of real estate for international buyers, collecting second homes as prestige acquisitions used for a few weekends a year, ties the Venetian housing market to global rather than local trends, dominated by corporate agents, with prices that rarely drop (Scheppe et al. 2009). Furthermore, especially after the austerity turn in European policy, a consistent share of the property owned by the public sector, including buildings of historical value and popular housing, started being liquidated on the private market to meet the financial needs of local, regional and state institutions, and are frequently re-functionalized into tourist facilities as hotels and restaurants (Salerno, 2019). This process occurs both in the HC and in the lagoon, where minor islands 


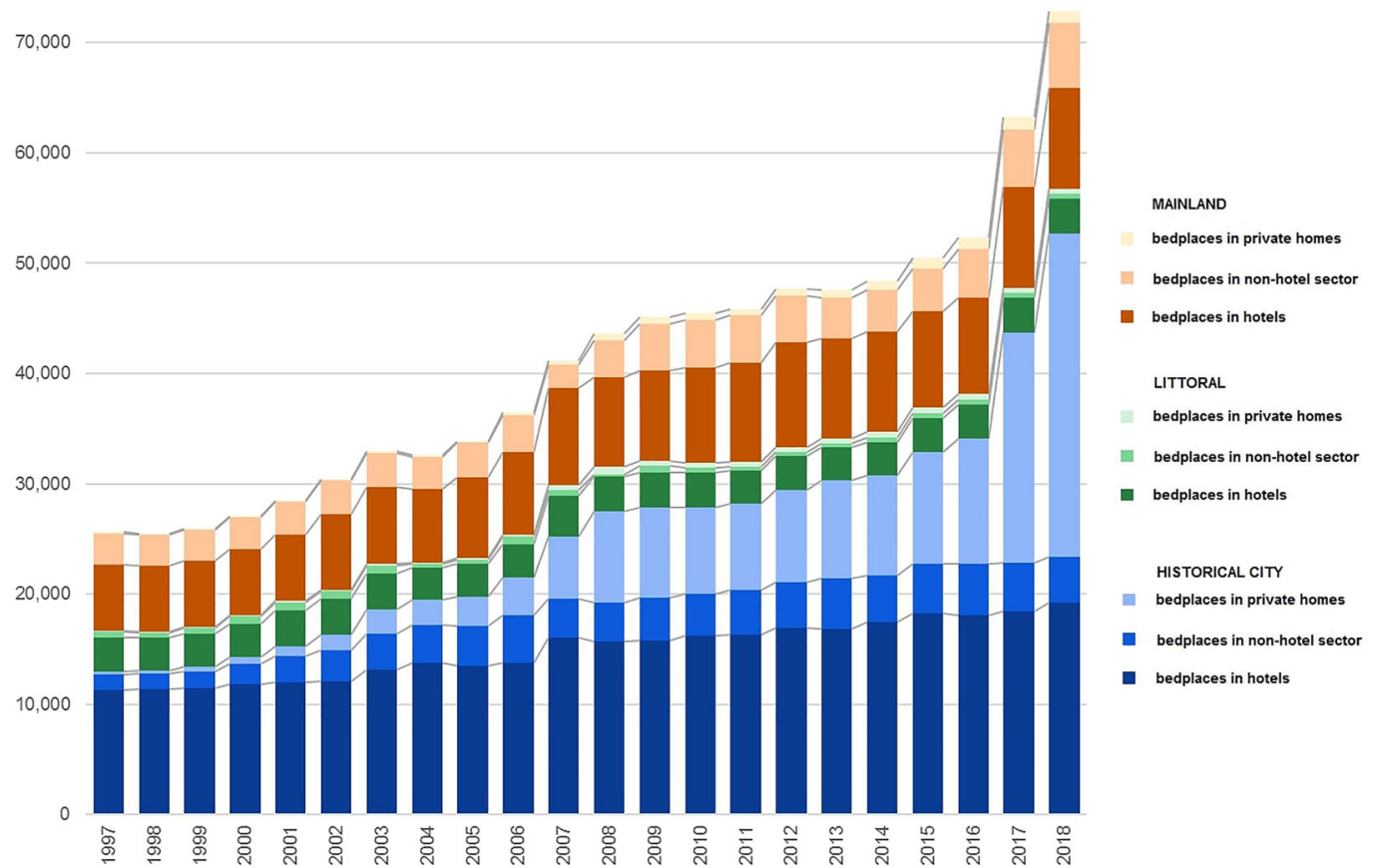

Figure 2. Evolution of accommodation supply in different sections of the Muncipality of Venice and by typology. Source: Alice Corona for OCIO (2020b) on data provided by Regione Veneto - Ufficio Statistica.

seems to have no other perspective of salvation from abandonment than being transformed into luxury resorts (Salerno, 2015). Those complementary elements, then, further illustrates how the ever-increasing tourism pressure reinforces the recursive loops by which touristification keeps growing towards monoculture (Cristiano \& Gonella, 2020) and urban rent "become the key driver of the local economy" (Fabbri et al., 2020, p.44).

The emergence and affirmation of STR platforms like Airbnb took these trends to the next level (see Figure 2). After a first period of introduction of the platforms (2010-2015), the growth of nonhotel supply accelerated, leading to the boom of the very last years. It is estimated by OCIO - a recently founded "grassroots civic watchdog on housing" - that between 2016 and 2018, 18,600 new tourist bedplaces have appeared in the HC, equalling the growth of the previous 15 years; in 2017 alone, the non-hotel supply registered a growth of $44.2 \%(57.4 \%$ in the $\mathrm{HC})$, while the hotel sector increased of only $3 \%$ ( $2 \%$ in the $\mathrm{HC}$ ) (OCIO 2020a, p. 210). The main role in this unprecedented expansion of supply has been played by platform-mediated STR, whose success is also significantly outcompeting other traditional forms of complementary accommodation, such as official $B \& B$ and guesthouses, reduced to 9,400 of the total 33,496 non-hotel bedplaces (OCIO 2020b). This process is also accompanied by a sort of "hotelization" of STR themselves, to be intended as the tendency to list each unit in a building on Airbnb and "thereby creating 'cottage hotels"' (Lee, 2016, p. 230), whose appearance in Venice has draw the attention both of independent grassroots organizations (OCIO 2020c) and law enforcements (Fullin, 2020).

The most recent official data published by Comune di Venezia (2017) indicate a total amount of 63,217 beds available in the entire municipality: 30,715 beds in hotels and 32,502 in other forms of accommodation, such as B\&B, guesthouses, rooms-to-let and above all apartments in STR regime. Of this total, the vast majority $(43,685)$ are located in the $\mathrm{HC}$ (excluding minor islands), including 18,384 hotel beds and 25,301 beds in other forms of accommodation. This scenario is constantly shifting: in February 2020, just before the COVID lockdown, the record was 


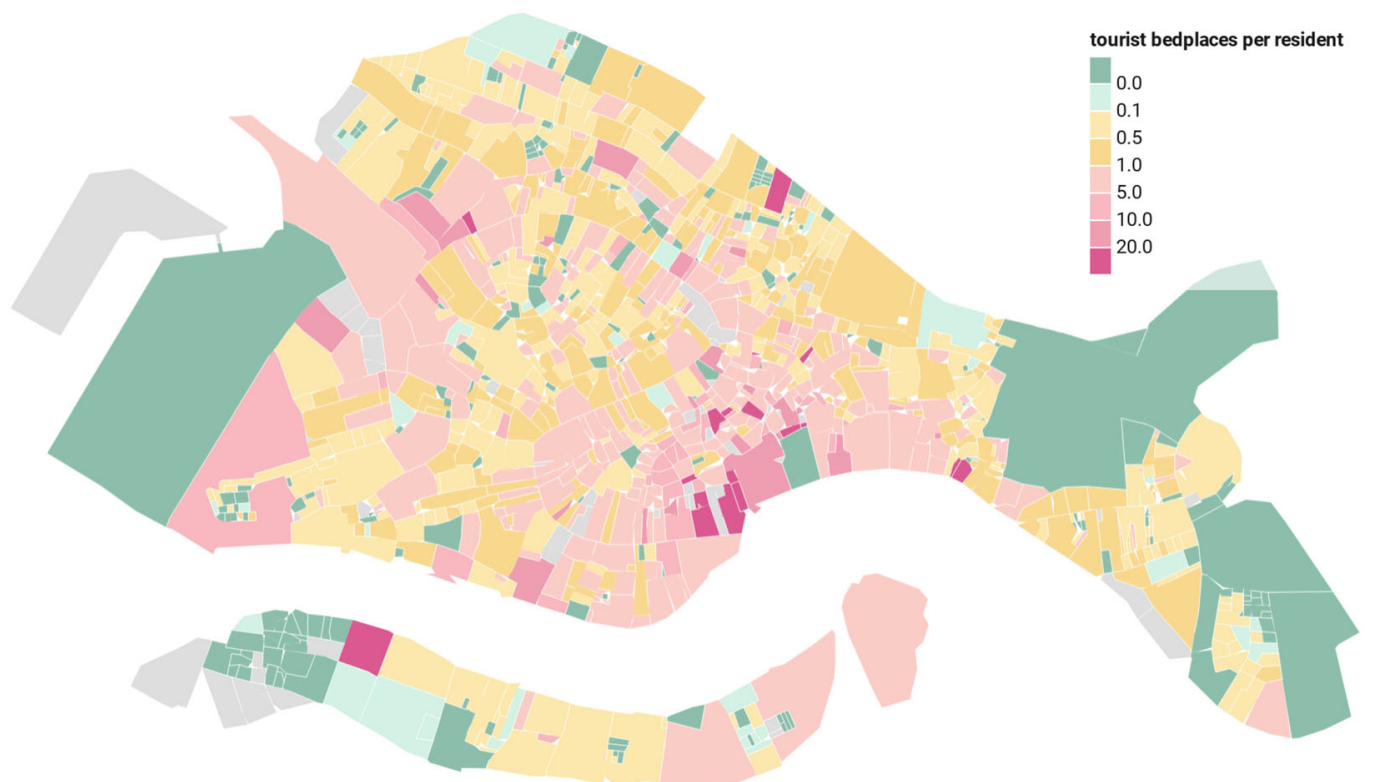

Figure 3. Bedplaces in all types of accommodation per inhabitant in Venice's census zones. Source: elaboration by Alice Corona on data provided by Population Register of the City of Venice and accommodation data included in the GeolDS portal of the City of Venice. Population and bedplaces data refer to June 24, 2020.

of 77,810 bedplaces spread over the entire municipal territory, of which 49,295 in the HC (the $63 \%$, including the $76 \%$ of the total number of bedplaces in STR), almost as many as its constantly declining 52,000 residents (OCIO 2020b). This concentration is not surprising, being the HC the traditional core of tourist supply; what actually does catch the attention is the distribution between accommodation types: 2017 marks the first year in which the supply in the non-hotel sector exceeded that of the hotel sector, which, just 20 years earlier, represented the $85 \%$ of the total. Moreover, besides the traditional anti-Airbnb public stance of the hotel industry, cases of hoteliers recurring to apartments in STR regime in order to extend their accommodation capacity have been registered (RESET, 2015), even if it is hard to evaluate the numeric significance of the phenomenon due to the unavailability of reliable data on the connection between management and property.

A closer look at the available data, such as in Corona's (2019) work for the independent research platform InsideAirbnb, reveals that in August 2019, 8,907 listings in Venice were advertised on Airbnb, three quarters of which consisted of an entire home or apartment, a growth of $14 \%$ over the previous year/month. The spatial distribution of the listings follows that of the overall accommodation supply, with a $76 \%$ of the total located in the HC. Corona estimates that the $12 \%$ of the housing units in the $\mathrm{HC}$ is on offer in Airbnb; the share of this supply that is occupied for more than 60 nights a year, the $46 \%$ of all listings, is likely to be removed from the residential market thoroughly. This equates to 3,338 homes in the $\mathrm{HC}$ alone. If we put together these different estimates of STR and the hotel data, almost a half of the geography of the HC thus experiences a tourist bedplace-per-inhabitant ratio of at least 1:1 (with areas where this ratio is even higher, up to 51,020 and more bedplaces per inhabitant). With very few lowintensity areas - also comprehensive of non-residential, monumental or infrastructural landcover - the high-intensity zones cover almost the totality of the $\mathrm{HC}$, sketching a geography of what we call the short-term city (Figure 3).

Another recent work nuances an even more problematic scenario than that depicted by Corona: using data directly offered by Airbnb itself, De Marchi (2019) calculates a global incidence of Airbnb listings on the housing stock of the HC ranging from $11 \%$ to $16 \%$. Airbnb however is not the only STR platform, and considering the supply of platforms such as Homeaway 
(3,876, of which $98 \%$ entire apartments), Housetrip (1,754 and 96\% namely) and Booking.com $(2,700$ and $83 \%$ namely), the incidence of STR prior to the COVID-19 crisis could be even stronger, as - according to the data sourcing agency AirDNA - the offer of those platforms is not completely overlapping with that of Airbnb.

Referring to Zannini's periodization of tourist development quoted above, it could be argued that the current situation may represent a third phase, inaugurated by the affirmation of platform capitalism. The boom of STR registered in 2016-2018 could be due in part to a measurement glitch, as more efficient control tools implemented by the administration in order to increase tax revenues may have resulted in the surfacing of a consistent amount of previously 'invisible' rental activity. However, it seems legitimate to affirm that the opening of the housing market to platform-mediated STR has enlarged the domain of tourist commodification to an unprecedented scale, boosting Venice's overtourism situation to a higher level of criticality and posing new fundamental challenges to the city.

\section{Debunking the debate: distributional effects and impacts of STR on the housing market}

The 'future of Venice' has been the object of intense debate in the last decades, locally and nationally, but also at international level given the universal historical and artistic value attributed to Venice. In spite of the countless statements, agreements, and publications promoting at least a mitigation of Venice's depopulation trends and environmental degradation, no effective solution to Venice's destiny as a tourist monoculture is in view, even if there seems to be today a certain agreement among social actors that the tourism trends presented in the previous section condemn the city to a bleak future. Yet the social and political landscape has changed radically in the last years, possibly also a sign of the increasing irrelevance of the $\mathrm{HC}$ as constituency and of the extreme dependence on tourism of the whole municipality, if not the whole Veneto region. The political turnover in 2015 - confirmed in 2020 - has represented a breakthrough shift for the concerns of the municipal administration. Until then, Venetian policy, which caters for a dynamic city that extends far beyond its insular historical limits, had always kept a close eye on the 'future of Venice' intended as preservation of the HC. However, most policy efforts to retain residents and jobs have met more failures than achievements.

As if this incapacity to revert trends had reached the state of entropy, the new administration has settled on simply monitoring visitor flows and cashing in tourist expenditure. A remarkable example of this new orientation has been the leeway given to the construction of a large stock of new budget accommodation establishments in the Venetian mainland. This might represent an affordable alternative for visitors that would come as excursionists and pay hotel taxes elsewhere; however, in the absence of any regulation on STR, is further enlarging the daily pressure on the $\mathrm{HC}$, exacerbating the boundary - functional and semiotic - between the insular shortterm destination and its periphery as 'sleeping quarters'. At the same time, statements of the new major against the residents of the $\mathrm{HC}$ who complain about excessive tourism pressure, have brought to light the how the interests of the mainland and of the $\mathrm{HC}$ are diverging also in policy discourses (Tantucci, 2016, 2018).

As a counterpart to this subtle 'turn' in policy, a new generation of social movements has taken the struggles for the protection of the lagoon and housing affordability - which characterised grassroots activism in the 1970s and 1980s - to a new level, achieving support even among middle classes and patrimonialistic institutions (Visentin \& Bertocchi, 2019). Their campaigns focus on tourism growth as the cornerstone of the many disruptions that threatens the social and environmental survival of the city, directly questioning the 'tourist destiny' of Venice as antithetical to a liveable and lived city. Their analyses and campaigns are aligned with those of the expanding international activist movements against touristification (Milano et al., 2019b), to 
which local collectives have contributed since the foundation of the SET Network - Southern Europe against Touristification (Borelli, 2019; Gainsforth, 2019; Pardo \& Gómez, 2019). Their main claims concern housing rights, the transformation of local commerce, the saturation of public space and transports, precarious employment and environmental issues related to the relentless growth of tourism and of the monocultural specialisation of urban destinations (SET 2018).

Many other actors at different scales are also involved in this debate, and most notably the extractive conglomerate that groups global actors like 'platform capitalism' organisations, small investors, large financial corporations, transport companies like cruise companies, and their local filières. Thus, the 'future of Venice' is now more than ever a discursive battleground. This debate has taken on many derivatives. Although we focus in this paper on the effects of STR on population dynamics, the policy implications of this debate go beyond the strict topic of housing use regulations, as they invest more broadly the struggle between rent extraction and urban resilience, of which housing is a key element and stress test (Paidakaki \& Moulaert, 2017a, 2017b).

\section{Sharing rhetorics and distributional effects}

There is no unanimity on the fact that the trends presented in the previous section represent an actual problem, in Venice or in any other city where the expansion of STR in recent years has substantially transformed the tourism landscape. The digital platforms themselves as Airbnb, from their side, have settled on a redistributive rhetoric, part of their peculiar strategy to deface mounting critiques to the role they are attributed as agents of gentrification and neighbourhood change, proposing instead a socially responsible corporate image through the mobilization of the hosts (Gainsforth, 2019; Sans \& Quaglieri Domínguez, 2016). In the specific case of Venice, the company actively intervened in the local political debate by positioning itself as an advocate of sustainable tourism, first of all adhering to the City Council's campaign \#EnjoyRespectVenezia with the production and diffusion of a video entitled "Live like a local in Venice", providing nothing more than basic information on the city's accessibility and instructions for waste recycle. In its 'Healthy travel and healthy destinations' report the company also affirmed that in Venice

crowding has become such an issue that the Mayor has considered limiting access mainly to overnight travellers, with prominent publications listing the city as a place to not visit in 2018. But with Airbnb, local hosts are actively promoting less-trafficked routes and local shops to their overnight guests, helping City Hall in its efforts to attract healthy, sustainable tourism. (Airbnb, 2018, p. 22)

These and other claims, as the fact that Airbnb spreads tourism off the beaten track to the advantage of lower-class areas that are neglected by the mainstream visitor economy, can be debunked with hard data proceeding from a variety of mostly case-study based (see for instance Gutiérrez et al. 2017 or Arias Sans \& Quaglieri Domínguez, 2016); our contribution here will be to bring out some evidence for the case of Venice.

More specifically on the topic of the distributional effects, Airbnb's public discourse insists on the fact that unlike corporate hotel chains, hosts on Airbnb keep up to $97 \%$ of the posted price to themselves. Hence, a dollar spent on the platform would be the one producing more benefits for the local economy, compared to the $14-36 \%$ of "chain travel dollars." They also claim that the "cruise line accommodations are the worst offenders in this exercise," with mostly no positive impact on the host community (Airbnb, 2018, pp. 10-12). However, the redistributive role of the STR platforms is increasingly contested. Not only the owners of valuable assets turn their homes into capital assets to earn rents, and such valuable consumer goods are typically concentrated in a small group of well-off people; but also, the marketplace for such valuable goods is very dynamic and getting concentrated in the hands of multi-proprietors, with a growing share of rental properties acquired by corporations or even rentiers following 'buy to rent' strategies (Cocola-Gant \& Gago, 2019). 
Table 1. Estimation of rents from different rental profiles and contracts. Source: De Marchi 2019, p. 231).

\begin{tabular}{lcr}
\hline Rental type & Cannaregio neighbourhood & Castello neighbourhood \\
\hline STR - typical host & $750 €$ & $661 €$ \\
STR - entrepreneurial host & $1,117 €$ & $1,503 €$ \\
STR - hotelier host & $1,475 €$ & $1,968 €$ \\
Residential contract $(3+2)$ & $941 €$ & $923 €$ \\
Residential contract $(4+4)$ & $804 €$ & $804 €$ \\
\hline
\end{tabular}

In the case of the Venetian market, the top $5 \%$ hosts by number of listings own the $30 \%$ of the total number of listings, and the top $5 \%$ hosts by estimated revenue accumulate the $35 \%$ of the total revenue stream generated by Airbnb listings in Venice (Corona, 2019). The pretended redistributive effect of the platform is then to be intended as significantly uneven, sharpening the already existing unbalance between tenants, who by definition have no real estate assets to rely on, and landlords: "it takes money to make money", as "with Airbnb, earning requires coming to the market with valuable assets" (Schor, 2017, p. 31). This uneven distribution is in line with the overall situation of the Italian Airbnb market, comparatively analysed in 2017 by Picascia et al. (2017) who look at Gini inequality indexes comparing the distribution of STR property and income distribution. Their study suggests the supposed benefits of the platforms are appropriated very disproportionately by a small number of users. In Venice, like in other 10 of 13 cities included in that study, the growth of the supply of STR has been paralleled by increasing income inequality, from a Gini index of 57 in 2015 to 60 in 2016.

Therefore, the famous Airbnb dollar does not equally land on the local economy, as the revenues are strongly unbalanced towards the top of the pyramid, and besides that they are getting increasingly concentrated in corporate hands. A closer insight on uneven distributional effects of STR in Venice has indeed been recently provided by De Marchi (2019), who compares the revenues of locating a housing unit in the residential or in the tourist market, under different scenarios in relation to the type of contract for the residential rent (formulas defined by the Italian law for the length of rental contracts, such as $3+2$ years and $4+4$ years, have different taxation levels) and to the average occupancy rate of tourist rentals. In this second case, three cases have been identified: the so-called "typical host" situation, that of an occasional tourist use with a relatively modest occupation rate (between $15 \%$ and $23 \%$ days/year); the entrepreneurial host, with an occupancy rate averaging 53\%; and the hotelier host, with an occupancy around $70 \%$.

The result of this exercise illustrates that revenues in general are superior with tourist rentals, yet, playing around parameters of costs and taxation schemes, tourist rentals are more advantageous than residential ones only when occupancy levels are superior to 50\% (De Marchi, 2019, p. 231). Taking as examples two popular and densely populated neighbourhoods, Castello and Cannaregio, the related estimations offer the results shown in Table 1.

Thus, tourist rentals in both areas are more competitive only at higher occupancy rates, providing a further explanation of why just the $27 \%$ of the hosts are non-commercial ('typical') and why, owning the $20 \%$ of the property on offer, they make only the $4 \%$ of the total revenue generated through platform listings (Corona, 2019). In short, market dynamics push for a professionalization of STR and its management in order to maximize revenues, and this applies also to the case in which there has been an investment to start STR activity. De Marchi (2019, p. 234) calculates that an entrepreneurial tourist location almost halves the amount of time necessary to recover a mortgage investment (in the example of the Castello neighbourhood, 23 years for entrepreneurial hosts, 17 years hotelier hosts, and an average of 40 years for a residential rent), and he clarifies that this is a prudential estimation. Moreover, investments that would be deterred by a high inflationary pressure would otherwise become attainable and may be larger in the case of properties with Airbnb-potential (Aalbers, 2019, p. 6).

This pressure towards professionalization exacerbates the already relevant crowding-out effects, pricing out both the non-commercial host and the resident, and fostering concentration 
of STR management and property. First of all, the small landlord, who was promised great revenues, is likely to face the choice between becoming a professional entrepreneurial host, or be driven out of the STR market by better performing competitors. Pushing an occasional host to maximize occupancy means that the management of reservation, check-in operations, cleanings and laundry is likely to be outsourced, fostering concentration of management in multi-listing commercial hosts, as noted in much recent research on this topic (e.g. Gil \& Sequera, 2020). By doing so, the dynamics of this marketplace pushes towards a situation in which hosts tend to become multi-proprietors, managing something that, rather than 'home sharing', appears to be a distributed hotel network, with rooms decentralized throughout the city, as in Venice, where $27 \%$ of the hosts control $63 \%$ of the listings (Corona, 2019); a trend not limited to whole apartments but also to room rentals, which in public discourse remains a practice more adherent to the genuine meaning of home-sharing (Quaglieri-Domínguez et al., 2020). Thus, we can identify a sort of second-level crowding-out effect: either the occasional host crowds out a resident by converting a residential unit in a de facto hotel, or he gets crowded out by more professionalised competitors who can further concentrate property through acquisition investments. As suggested for instance by Frenken and Schor (2017) or Yrigoy (2019), these trends uncover questions of class (already well-off home owners will profit most) but also the overarching power of mobile dwelling, determining an uneven negotiation for home - a 'mooring' device - at the cost of 'stable' populations (López-Gay et al., 2020).

\section{Price escalation and crowding-out}

Obviously, the related impacts of STR on the residential housing market are equally unmentioned by the platform campaigns. Several studies conducted in different territorial contexts (Cocola-Gant \& Gago, 2019, García-López et al., 2020; Lee, 2016; Wachsmuth et al., 2017; Wachsmuth \& Weisler, 2018) highlight how the housing market becomes increasingly unaffordable to long-term residents under the pull of STR. As a growing number of housing units is subtracted from residential market and converted to tourism use, long-term tenants are increasingly crowded out, as they are "no longer bidding against the local residential rent price, but instead against the extra profit that STRs can bring" (Lee, 2016, p. 238). Besides, housing market exclusion in high-intensity STR areas (such as most historical cores in European urban destinations) is also related to non-economic factors, as the conflicts arising to the mixed tourist and residential uses of buildings and surrounding public spaces, or the erosion of the support systems for everyday life such as gentrifying commercial supply or social networks (López-Gay et al., 2020). So the tendency towards "hotelization" and realization of "cottage hotels" is reinforced by a snowball effect as the conversion of residential units to STR increase the displacement pressure on other tenants (Cocola-Gant \& Gago, 2019), further reducing the housing supply and the overall resilience of the housing system in a loop of "self-destroying feedbacks" (Cristiano \& Gonella, 2020, p. 10).

Yet, in Venice as elsewhere, these critiques to the 'airbnbization' of cities are not universally recognized. For example, De Marchi argues that the incidence of STR in the housing stock replicates cadastral surveys on empty dwellings, nuancing a potential positive impact of sharing accommodation on the use of idle residential spaces (De Marchi, 2019, p. 229). In fact, Venice counted around $10 \%$ of empty housing units before the rise of STR, a percentage - the highest among all Italian regional capitals - that is easily explained by the very high maintenance costs. Hence, STR allegedly had the effect of 'filling the voids' in a strongly under-utilised urban fabric, providing an incentive for valorising property otherwise not rehabilitated. More in general, agents who benefit from the visitor economy (like ABBAV, the association of hosts and property managers) deny the correlation between growth or STR and depopulation by claiming that the exodus began long before the rise of non-hotel accommodations or the more recent affirmation of platform hospitality. In their view, STR are a virtuous way not only to valorise and maintain 
idle assets (i.e. abandoned or empty residential units) but also to create 'local' jobs to sustain the city economy (Dianese, 2020). To make this position more explicit, ABBAV hijacked in 2019 a slogan of the Venetian social movements, "mi no vado via" ("I will not leave") by reformulating it in "anca mi no vado via" ("I will not leave either"), suggesting that tourism rentals were allowing more Venetian residents to stay put in front of a strong gentrification pressure. For their part, grassroots movements contested these claims as unprovable and misleading (OCIO 2019), and several arguments can be moved against the proprietors assertions.

For instance, there is little doubt that the depopulation of Venice started well before the appearance of STR platforms, but it could be argued that if the same exodus is related to more complex urban dynamics occurred during the 20th century (zoning policies, suburbanization, new housing standards, demographics), the tourist specialization of the city is definitely part of those dynamics. While a proper examination of the relation between the growing tourist arrivals in the city and population loss of the HC (COSES 2009a) came to the conclusion that there was no direct causation, apparently supporting ABBAV's thesis, this study did not have the chance to consider the impact of STR after 2010 and the related challenges on housing affordability. Besides, it recognized that it remains to be questioned "how much of this property stock would have remained unused without tourism (or at more accessible market prices)" (ibid, 50); thirdly, it acknowledged that "the part of the real estate stock intended for residential use 'freed' by the resident population (...) was promptly reused for contested purposes (ibid.). Hence, if tourist reconversions, in a first stage, could have effectively just 'filled the voids', they may have become a hindrance to residential uses in a later stage when STR were came to be boosted by platform intermediation and professionalised through a concentration of property. In the first place, by making the available stock for medium- or long-term rents scarcer, and thus raising its cost (Lee, 2016; Yrigoy, 2019); secondly, by favouring evictions, as argued by Fava (2018) and targeted by grassroots social movements through denounce and direct action (Ghiglione, 2018; Rossi, 2018).

The emerging problem of crowding out of residents specifically due to the competition with STR, noted by De Marchi (2019) in his albeit prudent work, is also expanding to another segment of the market which presented in the past large speculative opportunities for landlords, such as student accommodation. This represents an additional threat for the social reproduction of the city. The student population at the two local universities, of which 8,000 (15\% of which were foreigners) were estimated to reside in the city during their studies (COSES, 2009b), has been identified as an antidote to the specialisation towards the low-end of tourism market and to ageing and depopulation processes (Russo \& Arias Sans, 2009). After a period dating approximately from the mid-1990s in which the opening of new student residences in the $\mathrm{HC}$ and housing renewal programs were starting to attract a younger population of 'cultural consumers' to reside in the city and to retain a sizable share of people formed in Venice, evidence shows that the 4-10\% increase in rental prices registered in 2017 and the intensification of tourism pressure through STR has started to force young people to the mainland (Fava, 2018), as they would do before the 1990s, when the strongly regulated room rental market was unaffordable for many. Once considered themselves gentrifiers, now students are being gentrified out of the city - but with much direr consequences in terms of the social fabric of the city, as skilled human capital loses any chance to 'make roots' and turn into social capital that will keep the city alive in the future.

A last important impact of STR on the housing market concerns the buying and selling dynamics. As we have seen, inoccupancy is a strong feature of Venetian housing stock, where "to the amount of unused units (19\%) a likewise quantity of houses occupied by non-residents must be added, thus releasing about $40 \%$ of housings from conditions of ordinary residential dwelling" (Fava, 2018). Nevertheless, in the context of STR the notion of emptiness is not immediate nor neutral, being possible that some of this empty units are relocated in the tourist market, a possibility that the emergence of platform STR has widely facilitated. If, for example, "a person were to buy a second home and rent it out to tourists permanently, that constitutes running a commercial lodging site, such as a B\&B or hotel" (Frenken \& Schor, 2017, p. 5), filling the 
voids of residents with temporary visitors. As it can be seen by real estate market reports, just "a $26.5 \%$ of home are bought for a first-home residential purpose, while respectively $26 \%$ and $29 \%$ are destined to investment and second home" (Fava, 2018). The Engel and Völkers (2019) market report states that the high demand from international buyers

ensures stability in the growth of the Venetian real estate market. The international customers who decide to buy a house in Venice make up about $70 \%$ of sales. (...) With a percentage of around $75 \%$, the market is characterized by customers who buy second homes to be used for investments, guaranteeing an excellent economic income often deriving from tourist rentals (8-10\% gross). (Engel \& Völkers, 2019, p. 18)

If on the other hand "only a quarter of buyers decide to buy a residential property in Venice for private use" (ibidem), it becomes clear that the new possibilities offered by the STR is also changing the second homes market, opening these traditional luxury acquisitions to the opportunity of a quick return on investment. Thanks to these new opportunities, corporations and individual investors increasingly use cities like Venice "as 'safe deposit box', a place to store their excess capital safely" (Aalbers, 2019, p. 6), giving place to a sort of generalized flat grabbing.

To conclude this section, the data presented here should support the claims that also in the Venetian case platform-mediated STR leads to "negative externalities in neighbourhoods and to shortages and rising prices in the long-term housing rental market", as recognized also by a report from the Joint Research Centre of the European Commission (Codagnone et al., 2016, p. 34). Despite the platform's attempts to be recognized as a positive actor in enhancing destinations sustainability, and the efforts of agents at multiple scales, from small-scale investors to corporate speculators and their local professional filières offering services to STR. advocating for this model, its growth is menacing the social fabric of cities, and Venice is no exception. To put it short, as Inside Airbnb's founder wrote, "Airbnb claim they are disrupting the hotel industry, when they are really disrupting the housing market" (Cox, 2017, p. 11).

\section{Final reflections and recommendations}

The trends presented in the above sections, involving material and socioeconomic transformations of the city, may be interpreted as a third phase of its tourism development trajectory, the ongoing realization of a short-term city. This new phase may be interpreted as closely associated with the higher gear that the structural changes of the contemporary globalized economy and rent extraction strategies have imposed on urban dynamics worldwide, and specifically transnational gentrification and the real estate market restructuring driven by now forms of dwelling 'on the move' (López-Gay et al., 2020; Sequera \& Nofre, 2018; Sigler \& Wachsmuth, 2016). Venice, as an international pole of attraction for leisure, culture and tourism activities, proved to be particularly exposed to this processes, with Airbnb and other STR platforms playing a key role in it, as they shift "the 'highest and best use' of residential housing" to tourist functions in order to realise rent gaps (Wachsmuth \& Weisler, 2018, p. 7). The geographical configuration of the city, where the physical separation of its insular tourist core from the productive socioeconomic landscape of the mainland accentuates a social stratification, is arguably a further element to explain the dimensions of this drift.

However, our presentation has highlighted that the case Venice offers insights for reflection also in terms of its 'capacity to respond' as part of a resilience strategy, showing that the socioeconomic changes it has been exposed to for a long time also have been paralleled by fundamental shifts in its political and discursive landscape. In fact, the current Venetian policy debate on overtourism seems outdated and the policies implemented or being discussed totally inadequate to tackle the global drivers that are pushing Venetians out of their city. The current municipal administration is apparently not taking such threats seriously. While its management approach combines a very basic promotion strategy with rhetoric claims on urban decorum, reflected by the \#EnjoyRespectVenezia campaign, other measures - like the continuously postponed adoption of the so-called 'access contribution' (an entry fee to the city, which should put 
a brake especially on 'bite and run' visits and levy some extra resources for conservation), or the much less ambitious 'revolving doors' access system occasionally put up to divert and spread out the incoming crowds, hardly address any of the challenges related to the residential market and the crowding out of locals. These policy attempts have also been noted to be very problematic in terms of equity and implementation costs (Salerno, 2018), let alone producing a dangerous semantic shift in the common perception of Venice from living urban entity to tourist compound, whose access can be controlled and charged for (see Arias Sans \& Russo, 2016, for an analogue critique).

This approach and the narrative of it that is aired through the media, rather than distancing from the TCC concept (as proposed by Fabbri et al., 2020) seems to look at it from a merely technical perspective, without considering the broader social sustainability and resilience implications. In this sense, the operationalisation of the TCC from a socioeconomic perspective (as in Costa \& Van Der Borg, 1988), whose target function is to maximize tourist revenues, controls for the negative externalities just inasmuch as they produce diseconomies for the tourist industry itself. It is then unsurprising that the consensus, hegemonic at least since the 1990s, that "what should be avoided at all costs is putting an explicit cap on the development of tourist accommodation, as Amsterdam and Barcelona are currently considering" (Van Der Borg et al., 2020, p. 13), is not at odds with the TCC policy target. It is claimed that capping or regulating supply in the HC would just "boost excursionism", seen as the worst performing mode of visiting the city; for the same reason "also the introduction of a tax on overnight stays (...) should be reconsidered. A tax on all the movements to and from the HC should take its place" (ibidem), sustaining by this means the model of a theme-park oriented urbanism, in which the access to the city is subject to pricing regulations.

Indeed, it can be noted that Van Der Borg himself in recent works has revised upwards the TCC threshold to 14 million (Van Der Borg, 2017) and again to 19 million visitors per year (Van Der Borg et al., 2020), taking in the calculus the extension of the local accommodation supply. These upwards revisions of the carrying capacity threshold, in a moment in which almost all social actors agree on the fact that the housing crisis threatens the very future of residence in the city, cast more than a doubt on the very aptness on the TCC framework to function as a policy target for a resilient city. This very author, in fact, claims that the TCC threshold is "a quantitative formulation of the original problem of how many tourists a destination can bear without compromising the quality of the tourist experience" (Van Der Borg et al., 2020). In a nutshell, it takes into account just the resilience of the tourist industry and not that of the urban organism, whose possibilities for conservation and reproduction (Russo, 2002a) are highly questionable in such conditions.

Based on the evidence presented in this paper, we believe that this conceptualisation of a 'sustainable tourist flow' and the related strategy (controlling for and taxing excursionism, but giving almost free rein to $\mathrm{HC}$ accommodation expansion as well as that of other visitor services such as mobility systems) would not necessarily alleviate overtourism, but definitely turn the city and its social and cultural complexity into a destination-product. Policies insisting on this model would align the definition of urban resilience to the specific resilience of its pro-tourism and progrowth subjects, i.e. to the needs of what we identified as the extractive conglomerate. To increase the sustainability of the tourism sector and enhance the resilience of the overall urban organism, it should be at the contrary necessary to envision different strategies, with the aim of overcoming the dependency on tourist resource and promoting a "bounce forward" outside the monocultural model. Indeed, one of the necessary foundations of a complex city, sustaining any type of socioeconomic renaissance compensating the dependence on a low value-added and extractivist industry like tourism (or anyway the tourist model Venice has been drifting towards in the last five decades), is residence. And affordable housing, challenged by the rise of STR, is precisely the battlefront which - in spite of the efforts of local grassroots social movements has received very little attention by the administration, possibly the reflection of a municipal constituency that due to the very dwindling of resident population in the $\mathrm{HC}$ is increasingly oriented to reaping short-term rents. 
While a regulation project for STR of the national government is stalled from years, and the regional government (whose territory largely 'predates' over destination-Venice as highlighted for instance in Russo, 2002a) is not likely to enforce any hard regulation, in a city where a sizable part of its housing stock is currently on offer in short-term rental platforms it is unlikely that this very social mass will support such decision. Yet a regulation is considered urgent if there can be a 'future for Venice' beyond that of becoming a short-term city, even more so when its evident lack of resilience is being proved by the ongoing pandemic crisis. Indeed, the economic slump provoked by the prolonged absence of tourists could possibly affect the city's capacity of recovery in its entirety, as not just the rentiers see their profits curtailed, but the overall economic system is at a standstill. It is then predictable that the negative effects of the COVID crisis will primarily affect the lowest income strata of the population, exposing the already fragile social tissue of the city to unemployment and evictions, and thus further endangering its capacity of social reproduction. A new orientation in economic and social policy is therefore necessary as ever, in the face of the scenario presented by the most recent evolution of the socio-political situation, such as the surge in the acquisition of bankrupt tourist activities by shady investors (Trevisan, 2020) or the protests by affected sectors and their workers towards the enforcement of security measures, which resulted in Covid denial actions (Gasparon, 2020).

Besides the emergency measures needed to avoid social and economic collapse, putting a cap on STR, as suggested by Wachsmuth et al. $(2017$, p. 3) (with the following specifications: one host, one rental; no full-time, entire-home rentals; platforms responsible for enforcement) seems a reasonable first step for public policies that aim to recover acceptable levels of retention of a stable population in Venice. A proposal in this sense, comprehensive of an analysis of its legal feasibility, has indeed recently been developed by OCIO (2020d). Regulating STR should however be just a part of a more complex strategy meant to pull back the city from the "phase transition" (D'Eramo, 2017), and should be accompanied by a cap on hotel licenses at a metropolitan level, thus including at least the whole Municipality of Venice, and possibly addressing the whole regional territory (whose vast implications and problematics we leave for further research). Moreover, a de-marketing strategy should take place, and more resources - for instance the income from tourist taxes - dedicated to fundamental housing policies. Finally, in order to stimulate the local economy to get beyond the actual extractivist tourist model and foster the overall resilience of the urban organism, stronger investments in a more diversified economy are badly necessary, out of a sound diagnostic of the differential factors that would make Venice's HC an attractive location. If none of this will happen, it is likely that 'short-term city Venice' will become more and more real and irreversible.

\section{Note}

1. The sharp decline in overnight stays in the minor islands and littoral zone in the year 2000 is a statistical glitch due to the secession of a section of the littoral; since that year, the overnight stays at Cavallino are not counted anymore in municipal statistics.

\section{Acknowledgments}

The authors wish to thank Alice Corona for the precious help on data collection and for the realisation of Figure 3.

\section{Funding}

Ministero dell'Istruzione, dell'Università e della Ricerca (MIUR), PRIN 2017EWXN2F; Spanish Ministry of Economy, Industry and Competitiveness (POLITUR project. CSO2017-82156-R), AEI/FEDER, and Department of Research and Universities of the Catalan Government (2017SGR22). 


\section{ORCID}

Giacomo-Maria Salerno iD http://orcid.org/0000-0001-5697-4830

Antonio Paolo Russo iD http://orcid.org/0000-0001-8768-246X

\section{Bibliography}

Aalbers, M. B. (2019). Introduction to the forum: From third to fifth-wave gentrification. Tijdschrift Voor Economische en Sociale Geografie, 110(1), 1-11. https://doi.org/10.1111/tesg.12332

Adger, W. N. (2000). Social and ecological resilience: Are they related? Progress in Human Geography, 24(3), 347-364. https://doi.org/10.1191/030913200701540465

Airbnb. (2018). Healthy Travel and Healthy Destinations report, web content: https://news.airbnb.com/wp-content/ uploads/sites/4/2018/05/Healthy-Travel-and-Healthy-Destinations.pdf

Arias Sans, A., \& Quaglieri Domínguez, A. (2016). Unravelling Airbnb: Urban perspectives from Barcelona. In G. Richards and A. P. Russo (Eds.), Reinventing the local in tourism. Producing, consuming and negotiating place (pp. 209-227). Channel View.

Arias Sans, A., \& Russo, A. P. (2016). The right to Gaudí. What can we learn from the commoning of Park Güell, Barcelona?. In C. Colomb \& J. Novy (Eds.), Protest and resistance in the tourist city (pp. 247-263). Routledge.

Barron, K., Kung, E., \& Proserpio, D. (2017). The sharing economy and housing affordability: Evidence from Airbnb. SSRN Scholarly Paper ID 3006832. Social Science Research Network, web content: https://papers.ssrn.com/ abstract $=3006832$.

Barbiani, E., \& Zanon, G. (2004). (Eds.). Condizioni di competitività delle strutture ricettive del Comune di Venezia e della regione turistica. COSES - Consorzio per la Ricerca e la Formazione.

Bettini, S. (1978). Venezia. Nascita di una città. Electa.

Bernardello, A. (2002). Iniziative economiche, accumulazione e investimenti di capitale (1830-1866). Storia di Venezia. L'Ottocento, vol. II, 567-601. Istituto della Enciclopedia Italiana Treccani.

Borelli, C. (2019). Overtourism e diritto alla città: il caso di Venezia. Il granello di sabbia, 40, 37-41. Attac Italia

Caserta, S., \& Russo, A. P. (2002). More means worse. Asymmetric information, spatial displacement and sustainable heritage tourism. Journal of Cultural Economics, 26(4), 245-260. https://doi.org/10.1023/A:1019905923457

Choay, F. (1996). L'allegoria del patrimonio. Officina Edizioni.

Celata, F., Sanna, V. S., \& De Luca, S. (2017). La "Airbnbificazione" Delle Città: Gli Effetti a Roma Tra Centro e Periferia. Università di Roma La Sapienza. Dipartimento MEMOTEF.

Cocola-Gant, A., \& Gago, A. (2019). Airbnb, buy-to-let investment and tourism-driven displacement: A case study in Lisbon. Environment and Planning A: Economy and Space, 1-18. doi:10.1177/0308518X19869012.

Codagnone, C., Biagi, F., \& Abadie, F. (2016). The passions and the interests: Unpacking the 'sharing economy. Institute for Prospective Technological Studies, JRC Science for Policy Report, European Commission.

Comune di Venezia. (1964). Atti del Convegno internazionale II problema di Venezia: Venezia, 4-7 ottobre 1962. Fondazione Giorgio Cini.

Comune di Venezia. (2017). Annuario del turismo 2017. Assessorato al Turismo.

Corona, A. (2019). Venezia. Inside Airbnb Infokit, 2019-08-12, web content: http://insideairbnb.com/venice/report. html

Consorzio per la Ricerca e la Formazione (COSES). (1979). Il turismo a Venezia. Venezia.

Consorzio per la Ricerca e la Formazione (COSES). (2009a). Rapporto 141.0 Turismo sostenibile a Venezia, web content: http://archive.comune.venezia.it/flex/cm/pages/ServeAttachment.php/L/IT/D/D.fe155294363b8b944ed1/P/ BLOB:ID $=28868$

Consorzio per la Ricerca e la Formazione (COSES). (2009b). Documento 1106.0 Città e università: il nodo delle residenze studentesche. http://coses.comune.venezia.it/download/Doc1106.pdf.

Cosgrove, D. (1982). The myth and the stones of Venice: An historical geography of a symbolic landscape. Journal of Historical Geography, 8(2), 145-169. https://doi.org/10.1016/0305-7488(82)90004-4

Costa, N., \& Martinotti, G. (2003). Sociological theories of tourism and regulation theory. In L. M. Hoffman, S. S. Feinstein, e D. R. Judd (a cura di). Cities and visitors. Regulating People, markets and city space. Op. cit.

Costa, P., \& Van Der Borg, J. (1988). Un modello lineare per la programmazione del turismo. Sulla capacità massima di accoglienza turistica del Centro Storico di Venezia. Coses Informazioni", 32, 33, 21-26.

Cox, M. (2017). Inside [the data of] Airbnb. The Devices of Tourism, Lo Squaderno 45, September 2017.

Cristiano, S., \& Gonella, F. (2020). Kill Venice': A systems thinking conceptualisation of urban life, economy, and resilience in tourist cities. Humanities and Social Sciences Communications, 7(1), 1-13. https://doi.org/10.1057/ s41599-020-00640-6

D’Eramo, M. (2017). Il selfie del mondo. Indagine sull'età del turismo. Feltrinelli.

Davidson, M., \& Lees, L. (2010). New-build gentrification: Its histories, trajectories, and critical geographies. Population, Space and Place, 16(5), 395-411. https://doi.org/10.1002/psp.584 
Davis, R., \& Marvin, G. (2004). Venice, the tourist maze. A cultural critique of the world's most touristed city. University of California Press.

Davoudi, S., Shaw, K., Haider, L. J., Quinlan, A. E., Peterson, G. D., Wilkinson, C., Fünfgeld, H., McEvoy, D., Porter, L., \& Davoudi, S. (2012). Resilience: A bridging concept or a dead end? Planning Theory \& Practice, 13(2), $299-333$. https://doi.org/10.1080/14649357.2012.677124

De Marchi, D. (2019). Le Venezie turistiche. In Quattro Venezie per un Nordest. Rapporto su Venezia Civitas Metropolitana 2019. Marsilio.

De Rita, G. (1993). Una Città Speciale: Rapporto su Venezia. Marsilio.

Dianese, M. (2020). "Bastonata" in arrivo per chi ha più case a Venezia e le affitta ai turisti, II Gazzettino 11/02/2020, web content: https://www.ilgazzettino.it/nordest/venezia/affitto_casa_vacanza_venezia_cosa_cambia-5044005. html

Engel \& Völkers. (2019). Market Report Venezia 2019, web content: https://issuu.com/engelvoelkers_italia/docs/market_report_2019_venezia

Fabbri, G., Migliorini, F., \& Tattara, G. (2020). Venezia, il dossier UNESCO e una città allo sbando. 2nd ed. Libreria Editrice Cafoscarina.

Fava, F. (2018). Vuoti di normalità. Evoluzioni della casa veneziana nell'era del turismo globale. Engramma, 155, April 2018.

Fregolent, L., \& Vettoretto, L. (2017). Genesis of a fluid metropolitan space. In A. Balducci, V. Fedeli, and F. Curci, (Eds.), Post-metropolitan territories: Looking for a new urbanity. Taylor \& Francis.

Frenken, K., \& Schor, J. B. (2017). Putting the sharing economy into perspective. In A research agenda for sustainable consumption governance. Edward Elgar Publishing.

Fullin, M. (2020). Ostelli e finti hotel in pieno centro: scattano i controlli di vigili e finanzieri, II Gazzettino.https://www. ilgazzettino.it/nordest/venezia/hotel_abusivi_centro_storico_finannza-4992046.html

Gainsforth, S. (2019). Airbnb città merce. Storie di resistenza alla gentrification digitale. DeriveApprodi.

García-López, M. À., Jofre-Monseny, J., Martínez-Mazza, R., \& Segú, M. (2020). Do short-term rental platforms affect housing markets? Evidence from Airbnb in Barcelona. Journal of Urban Economics, 119, 103278. https://doi.org/ 10.1016/j.jue.2020.103278

Gasparon, M. (2020). Protesta contro Dpcm e chiusure: «Via le mascherine», caos a Venezia, II Gazzettino. https:// www.ilgazzettino.it/nordest/venezia/dpcm_protesta_senza_mascherine_cosa_e_successo-5565477.html

Gheno, M. (2016). Anamnesi dell'abbandono. In L. Fregolent, M. Gheno, e F. Ferronato (Eds.), Laboratorio Venezia. Università IUAV di Venezia.

Ghiglione, G. (2018). Occupy Venice: 'We are the alternative to the death of the city', Guardian Cities. https://www.theguardian.com/cities/2018/sep/13/occupy-venice-alternative-to-death-of-city-activists-tourism

Gil, J., \& Sequera, J. (2020). The professionalization of Airbnb in Madrid: Far from a collaborative economy. Current Issues in Tourism, 1-20. https://doi.org/10.1080/13683500.2020.1757628

Gössling, S., Scott, D., \& Hall, C. M. (2021). Pandemics, tourism and global change: A rapid assessment of COVID-19. Journal of Sustainable Tourism, 29(1), 1-20. https://doi.org/10.1080/09669582.2020.1758708

Grove, K. (2013). Hidden transcripts of resilience: power and politics in Jamaican disaster management. Resilience, 1(3), 193-209. https://doi.org/10.1080/21693293.2013.825463

Gutiérrez, J., García-Palomares, J. C., Romanillos, G., \& Salas-Olmedo, M. H. (2017). The eruption of Airbnb in tourist cities: Comparing spatial patterns of hotels and peer-to-peer accommodation in Barcelona. Tourism Management, 62, 278-291.

Indovina, F. (1988). Turisti, Pendolari, Residenti. COSES Informazioni, 32/33, 27-36.

James, H. (1888). The aspern papers. Reprint. Penguin. 1986.

James, H. (1909). Italian Hours. Reprint. Penguin. 1995.

Lanapoppi, P. (2015). Caro turista. Corte del Fontego.

Lee, D. (2016). How Airbnb short-term rentals exacerbate Los Angeles's affordable housing crisis: Analysis and policy recommendations. Harv. L. \& Pol'y Rev, 10 (2016), 229.

Lefebvre, H. (1970). La révolution urbaine. Gallimard.

Lew, A. A. (2014). Scale, change and resilience in community tourism planning. Tourism Geographies, 16(1), 14-22. https://doi.org/10.1080/14616688.2013.864325

López-Gay, A., Cocola-Gant, A., \& Russo, A. P. (2020). Urban tourism and population change: Gentrification in the age of mobilities. Population Space and Place. https://doi.org/10.1002/psp.2380

Mann, T. (1912). Tod in Venedig. Translated. Death in Dover Publications. 1995.

Mehmood, A. (2016). Of resilient places: planning for urban resilience. European Planning Studies, 24(2), 407-419. https://doi.org/10.1080/09654313.2015.1082980

Meriläinen, E. S., Fougère, M., \& Piotrowicz, W. (2020). Refocusing urban disaster governance on marginalised urban people through right to the city. Environmental Hazards, 19(2), 187-208. https://doi.org/10.1080/17477891.2019. 1682492

Milano, C., Novelli, M. \& Cheer, J. (Eds.). (2019a). Overtourism: Excesses, discontents and measures in travel and tourism. CABI. 
Milano, C., Novelli, M., \& Cheer, J. M. (2019b). Overtourism and degrowth: a social movements perspective. Journal of Sustainable Tourism, 27(12), 1857-1875. https://doi.org/10.1080/09669582.2019.1650054

Minoia, P. (2017). Venice reshaped? Tourist gentrification and sense of place. In N. Bellini \& C. Pasquinelli (Eds.), Tourism in the city: Towards an integrative agenda on urban tourism. Springer International Publishing.

Momigliano, A. (2020). Venice tourism may never be the same. It could be better. The New York Times (3 July 2020). https://www.nytimes.com/2020/07/02/travel/venice-coronavirus-tourism.html.

Osservatorio Civico sulla Casa e sulla Residenzialità (OCIO). (2019). Fact-Checking: Affitti turistici: favoriscono o ostacolano la residenza? Alcune considerazioni. Available at: https://ocio-venezia.it/fact-checking/locazioni\%20turistiche/ abbav/2019/12/04/abbav/

Osservatorio Civico sulla Casa e sulla Residenzialità (OCIO). (2020a). Abitare la città. Politiche della residenza ai tempi del turismo. In G. Fabbri, F. Migliorini, \& G. Tattara, (Eds.), Venezia. Il dossier unesco e una città allo sbando., cit.

Osservatorio Civico sulla Casa e sulla Residenzialità (OCIO). (2020b). Gli squilibri del turismo veneziano, web content: https:/ocio-venezia.it/pagine/affittanze-dati/

Osservatorio Civico sulla Casa e sulla Residenzialità (OCIO). (2020c). Campo San Zan Degolà a Santa Croce (Venezia): un luogo dimenticato dalla calca ... ma non dagli speculatori (ed. Corona, A.). https://medium.com/ocio-venezia/ campo-san-zan-degolà-a-santa-croce-venezia-un-luogo-dimenticato-dalla-calca-ma-non-dagli-5ad3c73fbb49

Osservatorio Civico sulla Casa e sulla Residenzialità (OCIO). (2020d). Regolamentare le locazioni turistiche è possibile, oltre che necessario. https://medium.com/ocio-venezia/regolamentare-le-locazioni-turistiche-è-possibileoltre-che-necessario-b5742d2dded2

Paidakaki, A., \& Moulaert, F. (2017a). Does the post-disaster resilient city really exist? A critical analysis of the heterogeneous transformative capacities of housing reconstruction'resilience cells. International Journal of Disaster Resilience in the Built Environment, 8(3), 275-291. https://doi.org/10.1108/IJDRBE-10-2015-0052

Paidakaki, A., \& Moulaert, F. (2017b). Disaster resilience into which direction(s)? Competing discursive and material practices in Post-Katrina New Orleans. Housing, Theory and Society, 35(4), 1-454. https://doi.org/10.1080/ 14036096.2017.1308434

Pardo, D., \& Gómez, R. (2019). Southern Europe as an anti-tourism political space. In E. Cañada (Ed.), Tourism in the geopolitics of the Mediterranean (no. 9, pp. 86-91). Alba Sud. Contrast Reports Serie.

Picascia, S., Romano, A., Teobaldi, M. (2017). The airification of cities: Making sense of the impact of peer to peer short term letting on urban functions and economy. Proceedings of the Annual Congress of the Association of European Schools of Planning, 11-14/07/2017. Lisbon.

Quaglieri-Domínguez, A., Arias Sans, A., \& Russo, A. P. (2020). Home sharing, city selling. Insights from the airbnbzation of Barcelona. City, (forthcoming).

Quinn, B. (2007). Performing tourism Venetian residents in focus. Annals of Tourism Research, 34(2), 458-476. https://doi.org/10.1016/j.annals.2006.11.002

RESET. (2015). Affitti turistici a Venezia - Una economia da far emergere e regolamentare, Reset Venezia. https://resetvenezia.it/2015/08/23/affitti-turistici-a-venezia-una-economia-da-far-emergere-e-regolamentare/

Rossi, R. (2018). Elderly woman with a sick son to be evicted to make way for tourist rental - but Venetian citizens block the way, Campaign for a living Venice. https://campaignforalivingvenice.org/2018/07/21/elderly-womanwith-a-sick-son-to-be-evicted-to-make-way-for-tourist-rental-but-venetian-citizens-block-the-way/

Russo, A. P. (2002a). The sustainable development of the heritage city and its region. Analysis, policy, governance [Thela Thesis] ISBN: 90-5170-670-7.

Russo, A. P. (2002b). The vicious circle of tourism development in heritage cities. Annals of Tourism Research, 29(1), 165-182. https://doi.org/10.1016/S0160-7383(01)00029-9

Russo, A. P., \& Arias Sans, A. (2009). Student communities and landscapes of creativity: How Venice-The world's most touristed city'-is changing. European Urban and Regional Studies, 16(2), 161-175.

Salerno, G. M. (2015). Ritorno alla Laguna. L'esperienza dell'associazione "Poveglia per Tutti" come esempio di ritessitura urbana. In C. Cellamare \& E. Scandurra (Eds.), Pratiche insorgenti e riappropriazione della città. SdT edizioni.

Salerno, G. M. (2018). Oltre i tornelli, Rivista II Mulino, web content: https://www.rivistailmulino.it/news/newsitem/ index/Item/News:NEWS_ITEM:4400

Salerno, G. M. (2019). Gondole d'acciaio sulla Laguna. Luoghi Comuni 1, 1, Castelvecchi

Salerno, G. M. (2020). Per una critica dell'economia turistica. Venezia tra museificazione e mercificazione. Quodlibet.

Scheppe, W, \& the IUAV Class on Politics of Representation (2009). Migropolis: Venice/Atlas of a global situation. Hatje Cantz.

Schor, J. B. (2017). Does the sharing economy increase inequality within the eighty percent? findings from a qualitative study of platform providers. Cambridge Journal of Regions, Economy and Society, 10(2):263-279. https://doi. org/10.1093/cjres/rsw047

Sequera, J., \& Nofre, J. (2018). Shaken, not stirred: New debates on touristification and the limits of gentrification. City, 22(5-6), 843-855. https://doi.org/10.1080/13604813.2018.1548819

Seraphin, H., Sheeran, P., \& Pilato, M. (2018). Over-tourism and the fall of Venice as a destination. Journal of Destination Marketing \& Management, 9, 374-376. 
Southern Europe against Touristification (SET). (2018). Manifesto. http://www.iut.nu/wp-content/uploads/2018/08/ RED-SET-Manifesto-Inglès.pdf

Shaw, K. (2012). The rise of the resilient local authority? Local Government Studies, 38(3), 281-300. https://doi.org/ $10.1080 / 03003930.2011 .642869$

Sigler, T., \& Wachsmuth, D. (2016). Transnational gentrification: Globalisation and neighbourhood change in Panama's Casco Antiguo. Urban Studies, 53(4), 705-722. https://doi.org/10.1177/0042098014568070

Srnicek, N. (2017). Platform capitalism. John Wiley \& Sons.

Tantucci, E. (2016). "Il futuro è a Mestre? Brugnaro tradisce Venezia". La Nuova Venezia, 31/05/2016. https://nuovavenezia.gelocal.it/venezia/cronaca/2016/05/31/news/il-futuro-e-a-mestre-brugnaro-tradisce-venezia-1.13574126

Tantucci, E. (2018). Caos di Carnevale, Brugnaro: "Andatevene in campagna". La Nuova Venezia, 29/01/2018. https:// nuovavenezia.gelocal.it/venezia/cronaca/2018/01/30/news/il-controcanto-di-brugnaro-1.16411171

Trevisan, E. (2020). Negozi e hotel, mezza Venezia in vendita. E gli albanesi se la stanno comprando, II Gazzettino, 27/ 09/2020. Available at: https://www.ilgazzettino.it/nordest/venezia/vendita_case_prezzi_asta_albanesi_comprano_ venezia-5490203.html

Vale, L. J. (2014). The politics of resilient cities: whose resilience and whose city? Building Research \& Information, 42(2), 191-201. https://doi.org/10.1080/09613218.2014.850602

Vale, L. J., \& Campanella, T. J. (2005). The resilient city: How modern cities recover from disaster. Oxford University Press.

Van Der Borg, J. (2017). Sustainable tourism in Venice: What lessons for other fragile cities on water? In Caroli, R., \& Soriani, S. (Eds.), Fragile and resilient cities on water: Perspectives from Venice and Tokyo. Cambridge Scholars Publishing.

Van Der Borg, J., Bertocchi, D., Camatti, N., \& Giove, S. (2020). Venice and overtourism: Simulating sustainable development scenarios through a tourism carrying capacity model. Sustainability, 12(2), 512.

Vianello, M. (2016). The No Grandi Navi campaign: protests against cruise tourism in Venice. In Protest and resistance in the tourist city (pp. 185-204). Routledge.

Visentin, F., \& Bertocchi, D. (2019). Venice: An analysis of tourism excesses in an overtourism icon. In C. Milano, M. Novelli, \& J. Cheer (Eds.).

Wachsmuth, D., Kerrigan, D., Chaney, D., \& Shillolo, A. (2017). Short-Term Cities: Airbnb's Impact on Canadian Housing Markets. A Report from the Urban Politics and Governance Research Group. School of Urban Planning, McGill University, web content: https://davidwachsmuth.com/airbnbreport/.

Wachsmuth, D., \& Weisler, A. (2018). Airbnb and the rent gap: Gentrification through the sharing economy. Environment and Planning A. 50(6), 1147-1170.

Yrigoy, I. (2019). Rent gap reloaded: Airbnb and the shift from residential to touristic rental housing in the Palma Old Quarter in Mallorca, Spain. Urban Studies, 56(13), 2709-2726. https://doi.org/10.1177/0042098018803261

Zanardi, C. (2020). La bonifica umana. Venezia dall'esodo al turismo. Unicopli.

Zannini, A. (2002). La costruzione della città turistica. In Storia di Venezia. L'Ottocento (vol. II, pp. 1123-1149). Istituto della Enciclopedia Italiana Treccani.

Zannini, A. (2014). Il turismo a Venezia dal secondo dopoguerra ad oggi. Laboratoire Italien, (15), 191-199. https:// doi.org/10.4000/laboratoireitalien.848 